\title{
ANALISIS KELEBIHAN DAN KEKURANGAN SERTA KEBERMANFAATAN MENGGUNAKAN SOFTWARE ACCURATE, MYOB, ZAHIR ACCOUNTING DAN PENERAPANNYA DI UNIVERSITAS INDRAPRASTA PGRI
}

\author{
Oleh: \\ Zeinora $^{1}$ \\ Desy Septariani ${ }^{2}$ \\ Program Studi Pendidikan Ekonomi \\ Fakultas Ilmu Pendidikan dan Pengetahuan Sosial \\ Universitas Indraprasta PGRI \\ Email: \\ zee.aurora@gmail.com
}

\begin{abstract}
The Purpose of study computer Accounting is to able students with variety of basic competence. In this various competencies students are expected to be able and applied basic concepts and have good quality accounting procedurs. This research aims to analyze useage software Accurate, MYOB and Zahir Accounting. In this research authors choose accounting sotfware that aims to compare advantage and disadvantage of use and benefit of that softwares. This study through literature, relevan research and publication related to the topic.
\end{abstract}

Keywords: Accurate, MYOB accounting, Zahir Accounting

\begin{abstract}
ABSTRAK
Tujuan mempelajari komputer akuntansi adalah untuk membekali mahasiswa dengan berbagai kompetensi dasar. Dengan berbagai kompetensi tersebut mahasiswa diharapkan mampu menguasai dan menerapkan konsep-konsep dasar dan prosedur komputer akuntansi yang benar. Penelitian ini bertujuan untuk membandingkan penggunaan software Accurate, MYOB dan Zahir Accounting. Dalam hal ini penulis memilih software akuntansi yang bertujuan untuk membandingkan kelebihan dan kekurangan penggunaan serta kebermanfaatan dalam software software tersebut. Kajian ini dilakukan melalui studi pustaka dengan membahas literatur serta publikasi yang terkait dengan topik makalah. Serta terapannya di Universitas Indraprasta.
\end{abstract}

Kata Kunci : Accurate, MYOB dan Zahir Accounting. 


\section{A. PENDAHULUAN}

Fenomena yang terjadi pada kebanyakan mahasiswa/i kurang tertarik dengan software aplikasi akuntansi dengan berbagai macam alasan dan latar belakang kekurang tertarikannya. Padahal berdasarkan analisa pendahuluan diatas, telah dijelaskan beberapa argumen tentang signifikansi peran tenaga-tenaga profesional di bidang aplikasi akuntansi. Alasan- alasan yang sering ditemui di lapangan adalah masalah kesan yang mereka tangkap dengan akuntansi adalah masalah yang rumit untuk dikerjakan mengenai catatan-catatan keuangan dan dengan segala macam prosedur yang harus dilalui hingga memperoleh laporan keuangan.

Untuk mengatasi permasalahan tersebut diatas, maka perlu dilakukan terobosan-terobosan dan pelelitian lebih jauh agar lebih banyak lagi mahasiswa yang berminat dan mau mendalami akuntansi khususnya software aplikasi akuntansi. Pentingnya pembukuan dan kompleksnya transaksi pada perusahaan dagang memicu berkembangnya sistem informasi khususnya dalam bidang akuntansi, yaitu dengan hadirnya berbagai perangkat lunak akuntansi di dalam perusahaan yang mendukung untuk memudahkan manusia untuk bertransaksi secara lebih cepat, praktis, efektif, efisien.

Secara umum, software atau perangkat lunak akuntansi ini adalah sebuah program aplikasi yang dirancang untuk mempermudah pekerjaan para akuntan dalam pencatatan transaksi sampai dengan laporan keuangan daripada melakukan pencatatan secara manual. Hal ini dapat mempercepat pekerjaan juga mendapatkan hasil yang lebih akurat. Contohnya pencatatan hutang uasaha atau pembelian, piutang usaha atau penjualan, biaya biaya, buku besar, dan berbagai macam kegiatan pencatatan akutansi lainnya untuk menghasilkan pelaporan keuangan sebagai pertimbangan untuk pengambilan keputusan. Beberapa perangkat lunak yang lazim digunakan adalah MYOB, Accurate, Zahir Accounting.

Sistem informasi menjadi alat terpenting untuk meningkatkan kinerja dan target dari sebuah perusahaan dan telah terintegrasi ke dalam kegiatan bisnis seharihari seperti akuntansi, keuangan, manajemen operasi, pemasaran, manajemen sumber daya manusia, atau fungsi bisnis utama. 1) Pemanfaatan sistem informasi akuntansi dalam bidang keuangan telah meningkat di segala aspek dan telah menjadi suatu tatanan sistem keuangan yang lebih rapih dan terstruktur. Dengan menggunakan software akuntansi terbukti dapat menekan biaya, memotong proses kerja yang panjang sehingga lebih cepat dan efisien, 2) Salah satu contoh software akuntansi adalah Zahir Accounting. Software akuntansi Zahir banyak menjadi pilihan yang dipakai di beberapa perusahaan karena ditinjau dari segi biaya dan tampilan yang mudah dipahami untuk pengguna karena sebagian besar memakai bahasa Indonesia yang mudah dimengerti oleh kalangan masyarakat luas, fenomena yang banyak terjadi, penggunaan software akuntansi MYOB, Accurate dan Zahir Accounting dirasa cukup baik untuk digunakan karena telah sesuai dengan salah satu tujuan utama sistem informasi yaitu untuk menyajikan informasi sebagai pendukung pengambilan keputusan, perencanaan, pengendalian. 3) Universitas Indraprasta sebagai lembaga pendidikan yang mendidik mahasiswa/mahasiswi untuk menjadi tenaga-tenaga handal dan profesional khususnya pada sektor keguruan dapat memposisikan dirinya sebagai mitra penyedia guru guru dan tenaga profesional yang 
akan mengisi bagian sumber daya manusia di perusahaan yang menangani bidang Akuntansi.

\section{B. KAJIAN PUSTAKA}

Dalam kajian pustaka ini, dibahas beberapa pengertian dasar yang menjadi bahasan dari kajian ini yakni Software MYOB, Accurate dan Zahir Accounting. Kemudian masing masing pengertian tersebut dikaitkan satu sama lain, sehingga dapat lebih menjelaskan apa yang menjadi dasar kajian ini.

\section{MYOB Accounting}

Program MYOB Accounting yang berfungsi mengotomatisasikan pembukuan secara lengkap, terperinci, dan akurat sehingga akan lebih memudahkan dalam membuat laporan keuangan dibandingkan dengan penggunaan secara manual.

Mind Your Own Business Accounting atau lebih dikenal dengan MYOB (Nofrizal, 2013), mengatakan bahwa, "salah satu software akuntansi umum yang cukup popular di Indonesia. MYOB merupakan integrated software artinya software ini berguna untuk merekam seluruh transaksi bisnis dan menghasilkan laporan keuangan secara otomatis".

Pada pembahasan komputer akuntansi salah satu materi yang akan dibahas adalah tentang MYOB accounting. Menurut (Kartasuro Supriyanta, Atun Yulianto, Sa'diyah Noor Novita Alfisahrin, 2015) keunggulan MYOB Accounting adalah mudah dimengerti dan dipelajari, sangat fleksibel dan langsung dapat dioperasikan, dan tanpa menuntut prasyarat yang harus dikerjakan sebelumnya, tumbuh sejalan dengan perkembangan perusahaan.

Menurut (Komputer, 2015) MYOB Accounting adalah sebuah paket software olah data akuntansi yang yang dibuat secara terpadu dan dapat digunakan hanya satu user saja. Sedangkan menurut (Pradhana \& Latifah, 2013) mengungkapkan bahwa MYOB Accounting merupakan salah satu software komputerisasi data akuntansi, sehingga untuk bisa menguasai MYOB Accounting dengan mengetahui dasar komputer, siswa tidak akan kaget ketika pertama kali mengoperasikan MYOB.

Selanjutnya menurut (Kartasuro Supriyanta, Atun Yulianto, Sa'diyah Noor Novita Alfisahrin, 2015) MYOB atau Minding Your Own Business merupakan salah satu software akuntansi berbasis komputer yang dibuat oleh MYOB Limited Australia. Software ini dapat digunakan untuk perusahaan jasa, dagang, industri menengah ke bawah, maupun perusahaan besar.

MYOB merupakan aplikasi dalam bidang akuntansi yang memiliki sistem otomatisasi pembukuan yang juga dapat mengintegrasikan secara lengkap seluruh fungsi akuntansi dalam satu program (Suharyono, 2019). Rinawati menjelaskan, MYOB stands for Mind Your Own Bussiness, which means to manage our own financial transaction. In general, the function of $M Y O B$ is the same as other accounting programs, i.e. to work on the accounting cycle and produce financial statements which are provided by MYOB Accounting. Three versions of MYOB are circulated in Indonesia, namely MYOB Basic, MYOB Accounting, MYOB Premier. 
MYOB Basic is the simplest and most affordable MYOB variant. It is not recommended for use in companies with complicated transactions and wishing to have complete financial statements. In MYOB Basic, neither Inventory module, Purchase module, stock card nor debt reports are available, and it cannot be sent to excel automatically. Meanwhile, MYOB Accounting has been equiped with a feature to trace stock. Conceptually speaking, accounting is referred to as perpetual stock records. Hence, every goods trasfer will be traced (incoming goods as a result of purchase or sales return and outgoing goods as a result of sales or purchase return). Finally, MYOB Premier is the variant with the most complete features. The mean differences between MYOB Premier and MYOB Accounting are the facilities in MYOB Premier to deal with multicurrency transaction, facilities to trace transfer between warehouses, and multiuser facility (Rinawati et al., 2017).

Berdasarkan beberapa pendapat ahli di atas dapat disimpulkan bahwa program MYOB Accounting adalah sebuah paket software komputerisasi data akuntansi yang disediakan untuk mempermudah seseorang melakukan pembukuan secara lengkap, cepat dan akurat dalam proses pelaporan keuangan di perusahaan jasa, dagang, industri menengah ke bawah, maupun perusahaan besar.

\section{Accurate Accounting}

Accurate adalah software yang dapat membantu pengusaha melakukan pencatatan pembukuan, transaksi penjualan, pembelian, inventory, serta penyusunan laporan keuangan hanya dalam beberapa langkah mudah serta cepat dan akurat. Accurate Accounting Software adalah produk CPS Soft yang merupakan aplikasi akuntansi murni yang dibuat dan dikembangkan oleh putra putri terbaik Indonesia. Selama lebih dari 10 tahun, Accurate terus mengalami perkembangan yang disesuaikan dengan kebutuhan dunia usaha di Indonesia. Dan dalam pengembangannya, Accurate selalu berpedoman pada Standar Akuntasi Keuangan dan Peraturan Perpajakan yang berlaku di Indonesia. Oleh karena itu, Accurate selalu direkomendasikan dan dipercaya oleh para pengusaha di Indonesia. Sejak diluncurkan pertama kali yaitu pada tahun 1999, Accurate menjadi perhatian para pebisnis di Indonesia. Hal ini terlihat dari pertumbuhan pengguna Accurate yang terus meningkat dari tahun ke tahun. Tingkat pertumbuhan pengguna Accurate per tahunnya rata-rata $25 \%$. Berdasarkan database pengguna per Januari 2011, jumlah pengguna Accurate telah lebih dari 40.000.

Pertama kali diluncurkan untuk kalangan umum pada bulan November 1999, dengan memanfaatkan event pameran komputer terbesar di Indonesia Indocomtech 1999 yang diselenggarakan JHCC, Jakarta. Versi yang diluncurkan pada waktu itu adalah versi 1.0, dengan nama Accurate 2000 Accounting Software. Berkat masukan dari user dan mengikuti perkembangan dunia usaha di Indonesia Accurate selalu membenah diri dan menyesuaikan dengan perkembangan.

Accurate accounting software dikembangkan sejak 1999 oleh PT. Cipta Piranti Sejahtera (CPS Soft Developer of Accurate software) dan telah diaplikasikan oleh lebih dari 50.000 pengguna dan bekerja sama dengan lebih dari 30 universitas terkemuka di Indonesia sebagai mitra Accurate. Software accurate ini dapat mengaplikasikan general ledger, cash/bank, inventory, purchase, sales, fixed asset dan tersedia untuk varian project dan manufaktur yang diaplikasikan diberbagai 
jenis dan skala usaha kecil menengah di bidang trading, distribusi, service atau manufaktur dan lain sebagainya. Fungsi utamanya yaitu sebagai software accounting yang cocok diaplikasikan dihampir semua jenis usaha baik trading, service, kontraktor, ataupun manufaktur (Khotmi \& Amrul, 2017).

Dengan software akuntansi seperti Accurate Accounting, transaksi dan prosedur akuntansi yang rumit dapat diprogram dengan lebih mudah. Hanya dengan menginput tanggal, kode akun dan jumlah transaksi dapat secara otomatis menghasilkan jurnal, posting buku besar, laporan biaya produksi dan laporan keuangan. Hal ini tentunya memberikan keuntungan bagi perusahaan dan sumber daya manusia dan dapat diselesaikan secara praktis, cepat dan akurat (Sukmajaya \& Andry, 2017).

\section{Zahir Accounting}

Zahir Accounting adalah software akuntansi yang digunakan untuk membuat laporan keuangan, mempunyai fasilitas yang terpadu (Hanafi, 2013). Software Zahir dirancang untuk memudahkan mengumpulkan, mengolah, menyimpan data transaksi pada perusahaan dagang. Dengan software Zahir maka kehilangan data akan dapat diminimalisasi pada setiap perusahaan, selain itu waktu yang dibutuhkan untuk mendapatkan data yang diperlukan akan jauh lebih cepat dan akurat, laporan interaktif yang menarik dan terintegrasi. Menurut (Hanafi, 2013) "Zahir Accounting merupakan software akuntansi yang dibuat secara terpadu (integrated software)". Zahir Accounting mempunyai beberapa keunggulan dibandingkan dengan software sejenis. Tampilan yang menarik baik dalam interface program maupun dalam penyajian laporan keuangan.

Wardani menyatakan bahwa software Zahir adalah sistem informasi akuntansi berbasis komputer yang digunakan oleh perusahaan, khususnya perusahaan dagang di Indonesia. Zahir salah satu program akuntansi lokal yang sangat populer di kalangan pelaku usaha kecil menengah karena sifatnya yang easy, simple, dan flexibel (Wardani, 2014).

Menurut (Wardani, 2014) Zahir Accounting adalah software akuntansi keuangan yang sangat inovatif, namun sangat berbeda dengan software akuntansi lainnya. Selain mempermudah pembukuan, dimana seluruh jurnal akuntansi dan laporan keuangan dibuat secara otomatis tanpa perlu mengerti teori akuntansi yang mendalam, Zahir Accounting juga akan mempermudah dalam mengambil keputusan bisnis, karena dilengkapi berbagai analisa laporan keuangan perusahaan, seperti analisa rasio, break even point analysis, berbagai grafik dan laporan interaktif yang menarik dan terintegrasi.

Zahir Accounting adalah software akuntansi yang digunakan untuk membuat laporan keuangan, mempunyai fasilitas yang integrated dan berdaya saing tinggi, dilengkapi dengan analisa laporan berupa grafik dan analisa rasio keuangan yang berguna untuk keputusan manajemen (Widianto, 2015).

Zahir Accounting merupakan software akuntansi yang dikembangkan oleh PT. Zahir Internasional yang didirikan pertama kali pada tahun 1996. Seiring dengan tingginya permintaan dan kebutuhan pasar akan piranti lunak aplikasi pengola laporan keuangan secara automatisasi pengembangan untuk aplikasi tersebut juga semakin maju. Hal ini dibuktikan dengan dirilisnya beberapa edisi 
software terbaru yaitu Zahir Accounting 6, Zahir Point of Sales 6, Zahir Point of Sales Mobile, Zahir Report Server 6, Zahir Sales Order Mobile, Zahir Enterprise Plus, Zahir Onlie, dan Zahir Simply Versi Android (Pratama \& Nurdiawan, 2019). Zahir Accounting pun mempermudah pencatatan akuntansi seperti dikutip dari (Nurochman et al., 2019) menganalisis dan merancang sistem informasi dengan membuat data pendukung dalam proses input data ke dalam sistem informasi akuntansi berbasis aplikasi Zahir dalam bentuk Microsoft Excel guna mempermudah direktur ataupun karyawan perusahaan dalam pengambilan keputusan untuk menentukan kebijakan perusahaan yang akan diambil, serta mempermudah pembuatan laporan keuangan untuk para investor dan pemerintah terkait pelaporan pajak secara akurat dan handal.

Zahir merupakan software yang simpel dan mudah digunakan. Sudah sangat banyak sekali perusahaan yang menggunakan software aplikasi namun tidak menuntut kemungkinan tidak selamanya memberikan dampak positif. Melalui Software Zahir Accounting ini maka akuntansi perusahaan dagang di Indonesia akan semakin mudah dalam melakukan pembukuan, mengolah, serta menyimpan data transaksi yang selama ini menggunakan cara umum (manual) (Aisya et al., 2019).

\section{METODE PENELITIAN}

Kajian ini merupakan sebuah conceptual paper terkait kelebihan dan kekurangan penggunaan serta kebermanfaatan menggunakan software accounting, melalui temuan data dan informasi yang berasal dari data sekunder, baik yang berasal dari textbook serta publikasi ilmiah. Juga catatan dari hasil penerapan yang dilakukan Universitas Indraprasta terhadap software Zahir Accounting yang digunakan ke dalam kurikulum pembelajaran.

\section{HASIL DAN PEMBAHASAN}

Tabel

Perbandingan Kebermanfaatan MYOB, Accurate, Zahir

\begin{tabular}{llll}
\hline \multicolumn{1}{c}{ Keterangan } & \multicolumn{1}{c}{ MYOB } & \multicolumn{1}{c}{ Accurate } & \multicolumn{1}{c}{ Zahir } \\
\hline $\begin{array}{l}\text { Kemudahan } \\
\text { penggunaan }\end{array}$ & Lama dipelajari & Cukup lama dipelajari & Lebih cepat dipelajari \\
Input Pajak & Kurang Relevan & Cukup Relevan & Sangat Relevan \\
Currency & Multi Currency & Multi Currency & Multi Currency \\
Fitur & Australia & Indonesia & Indonesia \\
PSAK & Belum sesuai dengan & Sudah sesuai dengan & Sudah sesuai dengan \\
& standar keuangan & standar keuangan & standar keuangan \\
& Indonesia & Indonesia & Indonesia \\
Biaya & Murah & Murah & Sedang \\
Konten & Cukup & Cukup & Lengkap \\
\hline
\end{tabular}

Perkembangan dunia bisnis bagi perusahaan sangatlah penting, untuk itu dalam menghasilkan informasi keuangan yang cepat dan benar harus dilakukan oleh perusahaan supaya dipercayai oleh para pengguna atau pemakai. Informasi ini salah 
satunya dapat dihasilkan dengan menggunakan aplikasi keuangan yaitu MYOB, Accurate, dan Zahir Accounting.

\section{Kelebihan MYOB}

a. Keunggulan aplikasi MYOB Accounting menurut (Kartasuro Supriyanta, Atun Yulianto, Sa'diyah Noor Novita Alfisahrin, 2015) adalah penggunaannya mudah dipahami untuk dipelajari, lebih fleksibel dan dapat digunakan langsung tanpa membutukan syarat sebelum memulai. (Komputer, 2015) menjelaskan bahwa keunggulan MYOB Accounting adalah penggunaannya mudah dimengerti, data yang dihasilkan lebih cepat dengan memiliki tingkat keamanan bagi user.

b. Pengolahan data akuntansi membutuhkan penginputan satu kali demi menghasilkan output dari transaksi transaksi yang ada. Informasi keuangan yang dihasilkan lebih cepat dan akurat jika dibandingkan dengan yang digunakan manual. Apabila terjadi kesalahan dalam penginputan data keuangan, MYOB akan langsung menunjukkan kodenya dan harus dilakukan penginputan yang benar sampai tidak ada kesalahan lagi.

c. MYOB Accounting akan menghasilkan data yang teliti sehingga tidak terdapat kesalahan dalam laporan keuangan baik neraca, laba rugi dan perubahan modal.

d. MYOB memiliki kata sandi sehingga hanya orang yang memiliki akses yang bisa melakukan pengimputan data. MYOB Accounting Menurut Pramono (2005) Memberikan fasilitas dalam membuat kata sandi demi mengamankan file yang dimiliki, sehingga yang telah menggunakan kata sandi maka MYOB Accounting akan memunculkan tampilan ulang untuk memasukkan kata sandi tersebut dan jika kata sandi yang dimasukkan salah, maka MYOB Accounting akan memunculkan kata sandi anda salah.

\section{Kekurangan MYOB}

Kelemahan yang dimiliki oleh Software MYOB Accounting menurut (Komputer, 2015) adalah tidak dilengkapi dengan aplikasi perpajakan, laporan keuangan yang tidak bisa dimodifikasi, tidak dilengkapi dengan modul pengelolaan aktiva dikarenakan tidak memiliki modul aktiva tetap, tidak bisanya menghasilkan laporan konsolidasi perusahaan multi-company, serta sulit mengelola barang konsinyasi.

\section{Kebermanfaatan MYOB}

a. Berkembang sejalan dengan mengikuti kemajuan perusahaan.

b. MYOB Dapat membuat laporan keuangan yang otomatis dan sempurna, serta tepat. Disamping itu MYOB juga bisa dioperasikan online dan offline.

c. Nilai lebih yang software MYOB Accounting adalah penggunaannya yang sangat fleksibel sehingga menghasilkan keamanan yang tinggi bagi para pengguna dengan memiliki kemampuan eksplorasi laporan ke excel yang tidak melalui proses ekspor impor. 


\section{Kelebihan Menggunakan ACCURATE}

Accurate 4 memiliki banyak perubahan yang memudahkan user dalam penggunaan akuntansi. (Rahmadian, 2015) memberikan beberapa keunggulan dari ACCURATE seperti Client Server Technology, Multi User dengan tiga tingkat kewenangan yaitu Create, Edit dan Report, Multi Currency dengan menghitung otomatis realize \& unrealized gain/loss, Multi Unit dengan tiga tingkat perhitungan unit setiap barang, Multi Warehouse (Banyak Gudang), Multi Discount (Discount Item, Discount Invoice, dan Discount Payments), Project \& Department ( versi Deluxe Edition dan Enterprise Edition), Real Time Processing dengan Backward \& Forward Transaction, Fungsi pilihan tampilan menu dalam bahasa Indonesia dan bahasa Inggris, Perubahan Desain template setiap voucher dan invoice, Report yang dapat dicustomize (designer) sendiri oleh user jika memahami proses report dengan Fast Report, Digit transaksi sampai dengan 15 digit dan dua decimal 920 trilliun (920.000.000.000.000,00), Keakuratan perhitungan kuantitas barang sampai dengan 4 desimal, Bisa custom financial statement dengan berbagai macam pengelompokan untuk tipe Balance Sheet dan Income Statement, Fasilititas Grouping di dalam item yaitu mengelompokkan beberapa barang dalam satu kelompok barang baru dengan tanpa proses penggabungan, Fasilitas Job Costing yaitu mengelompokkan barang dalam satu kelompok barang baru dengan proses penggabungan dan dengan nilai cost yang baru, Fitur Extract Import yang memungkinkan Anda mengekstrak transaksi penjualan dari perusahaan cabang untuk dikirimkan ke perusahaan pusat, Biaya yang terjangkau mulai dari Rp 8.000.000,00 tanpa perlu adanya tambahan biaya pemeliharaan baik bulanan ataupun tahunan.

\section{Kekurangan ACCURATE}

Accurate selain memiliki manfaat, aplikasi ini juga memiliki beberapa kekurangan yaitu:
a. Aplikasi accrurate ini tidak bisa dicostum oleh pengguna
b. Accurate tidak mencakup semua kegiatan operasional perusahaan
c. Accurate tidak memiliki training pembelian baru.(Ananta, 2019)

\section{Kebermanfaatan ACCURATE}

a. Mahasiswa memperoleh ilmu tentang pengoperasian serta bagaimana penerapan yang sesungguhnya pada perusahaan dan juga mempelajari cara menganalisa kebutuhan perusahaan serta menambah pengalaman kerja sebagai konsultan sistem informasi.

b. Adanya sistem informasi Accurate yang digunakan oleh perusahaan manufaktur akan membantu proses bisnis yang dijalankan dan pencatatan keuangan perusahaan. Dengan aplikasi yang dimiliki dapat mempercepat kerja karyawan dalam melakukan pencatatan transaksi keuangan sehingga meningkatkan efisiensi memanajemen data perusahaan. 


\section{Kelebihan ZAHIR}

Aplikasi akuntansi lainnya yang digunakan oleh perusahaan untuk mengelola data keuangan adalah Zahir Accounting. Zahir Accounting akan menghasilkan laporan keuangan yang benar, mudah dipahami,fleksibel dan tepat waktu bagi para pemakai laporan keuangan, baik itu dari dalam perusahaan maupun pihak dari luar perusahaan. Zahir Accounting sudah dilengkapi dengan aplikasi perpajakan. Kelebihan dari aplikasi zahir yang digunakan oleh perusahaan adalah sebagai berikut:

a. Zahir Accounting adalah aplikasi akuntansi yang dirancang untuk mengelola keuangan perusahaan agar lebih mudah, fleksibel dan lengkap dan dapat pakai oleh perusahaan jasa, dagang maupun perusahaan manufaktur. (Komariah Nur, 2017) Kelebihan yang dimiliki oleh aplikasi ini adalah dilengkapi dengan Bahasa Indonesia, dapat dioperasikan dengan mudah, sistem akuntansi berstandar Indonesia dengan System Double Entry, mudah dalam mencetak faktur pajak dan standar, mempunyai nilai transaksi 15 digit, dilengkapi dengan fasilitas Giro Mundur dan harga murah.

b. Laporan keuangan yang tepat dan cepat yang dihasilkan oleh Zahir Accounting sudah tidak diragukan lagi.

Keunggulan lain yang dimiliki zahir accounting juga dipaparkan oleh (Yuska Desmahary $1 \& 1,2016$ ), antara lain (1) mudah dioperasikan oleh pengguna non akuntan, (2) dilengkapi dengan formulir khusus untuk pengimputan semua transaksi yang dilakukan perusahaan, (3) rancangannya yang lebih menarik dan mudah dipahami , (4) Laporan yang dihasilkan bisa langsung diemail dan diexport ke format lain, (5) Semua hasil laporan bisa di export untuk pengolahan data sesuai dengan kebutuhan para pemakai, (6) Tidak ada perbedaan hasil export dengan yang ada di program zahir, (7) Memiliki Berbagai format file hasil export, sehingga pengolahan laporan dapat dilakukan lebih mudah.

\section{Kekurangan ZAHIR}

Aplikasi zahir juga memiliki beberapa kekurangan atau kelemahan diantaranya sebagai berikut:

a. Zahir Accounting memiliki harga lisensi yang lebih mahal antara dari 2 juta per user sampai dengan 25 juta per user, tergantung pada tipe spesifikasi software yang digunakan.

b. Biaya per jam dan per buruh tidak bisa dihitung pada akuntansi biaya. Biaya yang ditampilkan adalah biaya alokasi, bukan yang sesungguhnya. Sehingga mengharuskan pengguna mengkalkulasi sendiri untuk hasil yang lebih akurat.

\section{Kebermanfaatan ZAHIR}

a. Menggunakan perangkat lunak aplikasi yang langsung menyediakan rumusrumus sehingga tidak perlu mengingat dan membuat rumus seperti yang ada excel 
b. Penginputan data pendukung dan transaksi bisa dilakukan langsung pada form yang tersedia dan akan langsung diproses secara otomatis.

c. Menghasilkan Laporan keuangan yang siap digunakan oleh pemakai

d. Laporan keuangan yang dihasilkan dapat digunakan untuk mengambil keputusan bisnis dengan cepat

Dalam menjalankan perusahaan, tantangan yang sering ditemui salah satunya adalah tentang bagaimana melakukan pengolahan data akuntansi perusahaan dengan memikirkan efisiensi waktu. Melakukan pembukuan dengan software Zahir Accounting merupakan salah satu cara yang ditempuh oleh perusahaan yang dimulai dari transaksi sampai dengan pengolahan data yang akan memberikan hasil yg baik dengan waktu yang singkat. Proses pengerjaan laporan keuangan ini dimulai juga dengan adanya bukti transaksi, membuat jurnal, buku besar dan neraca saldo.

Pengerjaan laporan keuangan dengan Zahir Accounting diawali dengan set up membuat data perusahaan, daftar rekening akun, satuan pengukuran yg digunakan, nama barang, pemasok dan pelanggannya, kode mata uang dan harta tetap yg dimiliki. Langkah yg kedua adalah membuka neraca standar yg dimiliki oleh perusahaan, yg diikuti dengan penginputan data transaksi yg telah terjadi dlm perusahaan. Setelah peng input an semua transaksi selesai, nanti akan diperoleh laporan keuangan perusahaan yg berupa laporan laba/rugi, neraca, arus kas dan rasio keuangan. Hasil laporan keuangan ini apabila dikerjakan dengan tepat dan benar tidak akan berbeda hasil akhirnya dengan penggunaan software MYOB dan accurate.

Praktek Zahir Accounting juga dilaksanakan pada mahasiswa Universitas Indraprasta pendidikan ekonomi semester 6 selama satu semester. Mahasiswa diwajibkan mengambil mata kuliah ini karena berkaitan dengan keilmuan yg mereka ambil yaitu dengan transaksi akuntansi dalam ekonomi dan bisnis. Disini mahasiswa dibimbing dalam menginput transaksi akuntansi yang terjadi pada perusahaan sampai dengan membuat laporan keuangan, serta menganalisis rasio keuangan yang terjadi di perusahaan. Dengan mengikuti mata kuliah ini mahasiswa nantinya bisa mempraktekkan ilmu yang diperoleh dalam kegiatan bisnis ekonomi sehari hari bahkan dalam dunia pekerjaan. Sehingga mahasiswa dari jurusan ekonomi Universitas Indraprasta diharapkan setelah lulus dari universitas Indraprasta mempunyai skill dalam membuat laporan keuangan dengan Zahir Accounting maupun software accounting lainnya. Universitas Indraprasta sudah menggunakan Zahir Accounting versi 6 yang terbaru.

Untuk lebih membekali lulusan pendidikan ekonomi yang akan bersaing di dunia bisnis di Universitas Indraprasta juga dibuka pelatihan sertifikasi Zahir Accounting yang bekerjasama langsung dengan perusahaan Zahir Internasional. Pelatihan ini dilaksanakan sekali dalam setahun selama satu bulan. Dalam pelatihan ini mahasiswa dibimbing oleh instruktur yang ahli. Mahasiswa dilatih utk bisa menginput transaksi keuangan dengan tepat dan cepat. Disini mahasiswa diberikan trik trik menginput transaksi akuntansi sampai menghasilkan laporan keuangan dengan tepat dan cepat. Jadi lulusan pendidikan ekonomi Universitas Indraprasta yg mengikuti pelatihan ini akan mendapat sertifikat keahlian membuat laporan 
keuangan dengan Zahir Accounting yang dikeluarkan oleh PT Zahir Internasional yang diakui dalam dunia kerja dan bisnis nantinya.

\section{E. SIMPULAN}

Berdasarkan penjelasan dan pembahasan, penggunaan perangkat lunak aplikasi komputer akuntansi, maka dapat disimpulkan:

1. Software Akuntansi menjadi sangat penting dalam membantu mempercepat penyelesaian penginputan dan pengolahan data transaksi maupun dalam hal pelaporan. Pengolahan data transaksi dengan Software Akuntansi berbasis komputer ini juga dapat mengurangi kesalahan-kesalahan yang terjadi contohnya mengurangi resiko salah pencatatan nomor bukti. Selain itu aplikasi ini memiliki tingkat keamanan yang cukup valid dibanding dengan pengolahan data akuntansi secara manual.

2. Software Accounting dapat diaplikasikan pada perusahaan kecil maupun berskala besar dan dapat dipelajari dengan mudah tanpa harus memiliki keahlian dalam bidang akuntansi. Meskipun begitu dalam pengalaman mengajar maupun pengalaman penulis sebagai Auditor, software Akuntansi ini dengan berbagai segala kelebihan ataupun kekurangan serta kebermanfaatannya kami lebih merekomendasikan Zahir Accounting karena Aplikasinya lebih familiar, mudah dipahami dan mendukung untuk dipakai di perusahaan, dagang ataupun tempat pelatihan serta Universitas yang memakai Software ini. 


\section{DAFTAR PUSTAKA}

Aisya, S., Askandar, N. S., \& Afifudin. (2019). Pengaruh Kemampuan Individual dan Norma Subyektif Terhadap Minat UMKM Se Kota Malang Untuk Menggunakan Zahir Accounting Software Dalam Membuat Laporan Keuangan. E-Jra.

Ananta, D. S. (2019). Penerapan Sistem Accurate pada Arus Kas di CV Anugrah Unika Mekanik Siduarjo.

Hanafi, Y. dan. (2013). Komputerisasi akuntansi dengan Zahir Accounting. Prestasi Pustaka.

Kartasuro Supriyanta, Atun Yulianto, Sa'diyah Noor Novita Alfisahrin, dan D. P. (2015). 4 In 1 Aplikasi Akuntansi yang Paling Dibutuhkan. MediaKom.

Khotmi, H., \& Amrul, R. (2017). PENERAPAN APLIKASI ACCURATE DALAM PENYUSUNAN LAPORAN KEUANGAN UKM (Studi pada UKM PT Tri Utami Jaya Mataram). Jurnal Valid.

Komariah Nur. (2017). No Title. Analisa Aplikasi Accurate 3 Studi Kasus PT Elektra Baru Sukses, Volume 8.

Komputer, T. L. W. (2015). Langsung Praktik Komputerisasi Akuntansi dengan $M Y O B$. Wahana Komputer.

Nofrizal. (2013). Menyelesaikan Siklus Akuntansi Perusahaan Dagang Dengan MYOB Accountright Premier V19 Untuk Siswa SMK Dan Awam. CV Andi Offset.

Nurochman, B., Wahyuni, N. I., \& Kustono, A. S. (2019). Rekonstruksi Sistem Informasi Akuntansi Pada PT. NURTIWI. E-Journal Ekonomi Bisnis Dan Akuntansi. https://doi.org/10.19184/ejeba.v6i2.11148

Pradhana, D. Y., \& Latifah, L. (2013). PENGARUH KOSA KATA BAHASA INGGRIS, DASAR KOMPUTER DAN AKUNTANSI TERHADAP PRESTASI BELAJAR MYOB Darojatun Yakti Pradhana 1 Lyna Latifah 2. Jurnal Pendidikan Ekonomi Dinamimika Pendidikan.

Pratama, F. A., \& Nurdiawan, O. (2019). Peningkatan Pemahaman Akuntansi Dengan Menggunakan Software Zahir. Edunomic Jurnal Pendidikan Ekonomi. https://doi.org/10.33603/ejpe.v7i2.2551

Rahmadian, M. C. (2015). Implementasi OSistem Informasi Akumtansi dengan Software Accurate pada Perusahaan Manufaktur. SEMINAR NASIONAL APLIKASI DAN PENGEMBANGAN TEKNOLOGI INFORMASI (SNAPTI), $60-67$.

https://dspace.uc.ac.id/bitstream/handle/123456789/895/Binder1.pdf?sequen $\mathrm{ce}=1 \&$ isAllowed $=\mathrm{y}$

Rinawati, T., Puspitasari, D., \& Lestari, H. S. (2017). AN ANALYSIS OF STUDENT'S COMPREHENSION LEVEL ON MYOB ACCOUNTINGBASED ACCOUNTING APPLICATION. Economics \& Business Solutions 
Journal, 1(2).

Suharyono, S. (2019). PENGARUH MYOB TEST CLINIC TERHADAP KOMPETENSI MAHASISWA. Jurnal Analisa Akuntansi Dan Perpajakan. https://doi.org/10.25139/jaap.v2i2.1229

Sukmajaya, I. B., \& Andry, J. F. (2017). AUDIT SISTEM INFORMASI PADA APLIKASI ACCURATE MENGGUNAKAN MODEL COBIT FRAMEWORK 4.1 (Studi kasus Pt. Setia Jaya Tekhnologi). Seminar Nasional.

Wardani, R. dan. (2014). Modul praktikum atau lab akuntansi zahir.

Widianto, K. (2015). KAJIAN PENGGUNAAN SOFTWARE ZAHIR ACCOUNTING DENGAN PENDEKATAN TECHNOLOGY ACCEPTANCE MODEL (Studi Kasus: Mahasiswa Program Studi Komputerisasi Akuntansi AMIK "BSI Bogor"). Jurnal Khatulistiwa Informatika.

Yuska Desmahary 1, H. K. 2, \& 1. (2016). Aplikasi Akuntansi Zahir Accounting Untuk Pengolahan Data Keuangan Pada PD. Nugraha Jakarta Yuska. JURNAL ONLINE INSAN AKUNTAN. 